\title{
Primary hepatic mucosa-associated lymphoid tissue lymphoma: a case report and literature review
}

\author{
Shigeyuki Nagata*, Norifumi Harimoto and Kiyoshi Kajiyama
}

\begin{abstract}
Primary hepatic mucosa-associated lymphoid tissue (MALT) lymphoma is an extremely rare disease. We herein describe the findings in a 74-year-old man with elevated liver enzyme levels. Dynamic computed tomography showed focal biliary dilation and atrophy in the posterior segment, while dynamic magnetic resonance images revealed a small, highly enhanced small mass located at the root of posterior branch of the biliary ducts. As the mass was not detected on abdominal ultrasonography, a biopsy could not be performed. Cholangiocellular carcinoma was suspected, and surgery was performed. However, the surgically resected hepatic tumor was a nodule of aggregated lymphocytes that formed a lymphoepithelial lesion. Immunohistochemical analysis revealed that the lymphoma cells were positive for CD20 and CD79a, but negative for CD3. No other lymphoid lesions were found during additional postoperative examinations. Therefore, the patient was diagnosed with primary hepatic MALT lymphoma. He was also diagnosed with Helicobacter pylori infection, and thus, pylorus eradication was performed. At the time of this report, the patient was free of disease for 2 years without any additional treatment. The present case contributed to the diagnosis and management of this rare disease, as previously published case reports described varying imaging features; it also suggested that preoperative diagnosis was often difficult without biopsy.
\end{abstract}

Keywords: Primary hepatic lymphoma; Mucosa-associated lymphoid tissue lymphoma; Hepatectomy; Helicobacter pylori

\section{Background}

Mucosa-associated lymphoid tissue (MALT) lymphoma is a low-grade malignant lymphoma that was first described by Isaacson and Wright in 1983 [1]. The stomach is one of the most common sites of MALT lymphoma development, and gastric MALT lymphoma is commonly associated with Helicobacter pylori (HP) infection. However, primary hepatic lymphoma (PHL) is very rare, accounting for approximately only $0.016 \%$ of all cases of all non-Hodgkin's lymphoma cases [2]. Furthermore, primary hepatic MALT lymphoma is extremely rare among the diagnosed PHL cases. In addition, the standard diagnostic method and treatment strategy of this disease have yet to be established. Herein, we describe a case of surgically resected primary hepatic MALT lymphoma, which was initially

\footnotetext{
* Correspondence: punchnagata@live.jp

Department of Surgery, lizuka Hosipital, Yoshiomachi 3-83, lizuka, Fukuoka 820-8505, Japan
}

\section{国

\section{Case presentation}

A 74-year-old man was referred to our department for mild elevation of liver enzyme levels. He had no significant medical history except for hypertension that was medically managed. His family history was unremarkable. Physical examination at presentation did not indicate any abnormalities. The laboratory tests conducted at our hospital showed the following findings: hemoglobin level of $17.4 \mathrm{~g} / \mathrm{dl}$, a platelet count of $204,000 / \mu \mathrm{l}$, albumin level of $4.5 \mathrm{~g} / \mathrm{dl}$, total bilirubin level of $0.6 \mathrm{mg} / \mathrm{dl}$, aspartate aminotransferase level of $22 \mathrm{IU} / \mathrm{L}$, alanine aminotransferase level of $34 \mathrm{IU} / \mathrm{L}$, lactate dehydrogenase level of $160 \mathrm{IU} / \mathrm{L}$, $\gamma$-glutamyltranspeptidase level of $36 \mathrm{IU} / \mathrm{L}$, alkaline phosphatase level of $338 \mathrm{IU} / \mathrm{L}, \mathrm{C}$-reactive protein level of $0.43 \mathrm{mg} / \mathrm{dl}$, IgG level of $2199 \mathrm{mg} / \mathrm{dl}$, and IgM level of $268.7 \mathrm{mg} / \mathrm{dl}$. Hepatitis B surface antigen and anti-hepatitis 
$\mathrm{C}$ virus antibody in the serum were negative. Anti-nuclear antibody and anti-mitochondrial antibody were also negative. Tumor marker levels including carcinoembryonic antigen, carbohydrate antigen 19-9, $\alpha$-fetoprotein, and des- $\gamma$-carboxy prothrombin were within the normal ranges.

Dynamic computed tomography (CT) with drip infusion cholangiography revealed focal dilatation of the biliary ducts and atrophy in the posterior segments of the liver without any observable mass (Fig. 1a, b). The magnetic resonance imaging (MRI) scans, T1- and T2-weighted images, did not show any mass. However, when gadolinium was used as a contrast agent, a $1.5-\mathrm{cm}$ mass located in the area adjacent at the main posterior biliary duct was highly enhanced on T1-weighted images during the arterial phase but demonstrated rapid withdrawal in the portal venous and delayed phases (Fig. 2). Gastroscopic and colonoscopic examinations showed no ulcerative or tumorous lesion. As the mass was not detected on abdominal ultrasonography (US) and it could possibly be a malignant tumor such as cholangiocellular carcinoma, the patient consented to undergo a right hepatectomy with lymph node dissection in the hepatic portal region. Grossly, a 7-mm white mass detected along with the posterior biliary duct was soft and non-encapsulated like a lymph follicle (Fig. 3a).

Histologically, dense lymphocyte infiltration with some lymphoid follicles was observed in the portal area (Fig. 3b). Small- to middle-sized lymphocytes showed no apparent atypia but formed lymphoepithelial lesions on some bile

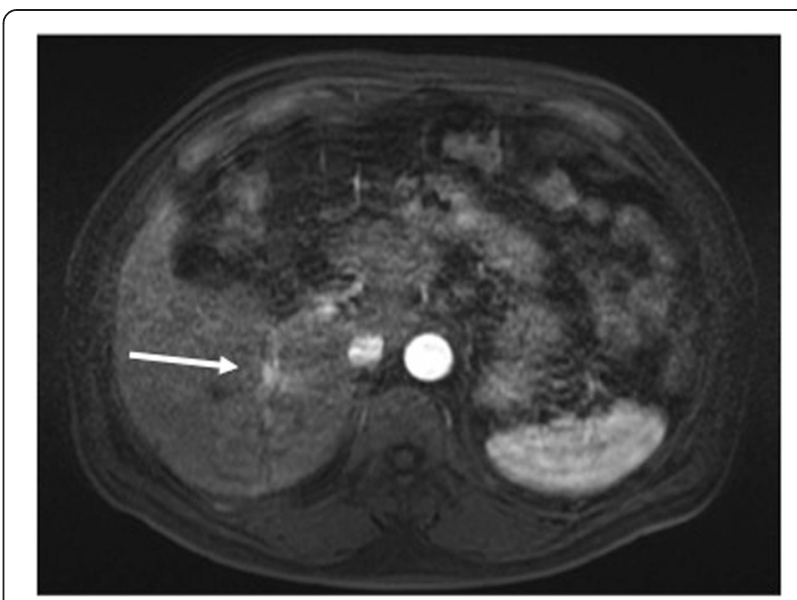

Fig. 2 Enhanced magnetic resonance imaging after gadolinium injection. The tumor was hyper-intense on T1-weighted images (arrow) in the area adjacent to the main posterior biliary duct in the arterial phase but showed rapid washout in the late phase

capillaries (Fig. 3c, d). Immunohistochemical studies indicated that the lymphocytes were positive for CD20 and CD79a (Fig. 4), but negative for CD3. The patient was diagnosed with low-grade hepatic MALT lymphoma based on the abovementioned pathological findings.

Subsequently, the patient's level of interleukin-2 receptor was found to be elevated at $1133 \mathrm{U} / \mathrm{ml}$ (normal range, $122-496 \mathrm{U} / \mathrm{ml})$. He was also infected with $\mathrm{HP}$ and medical
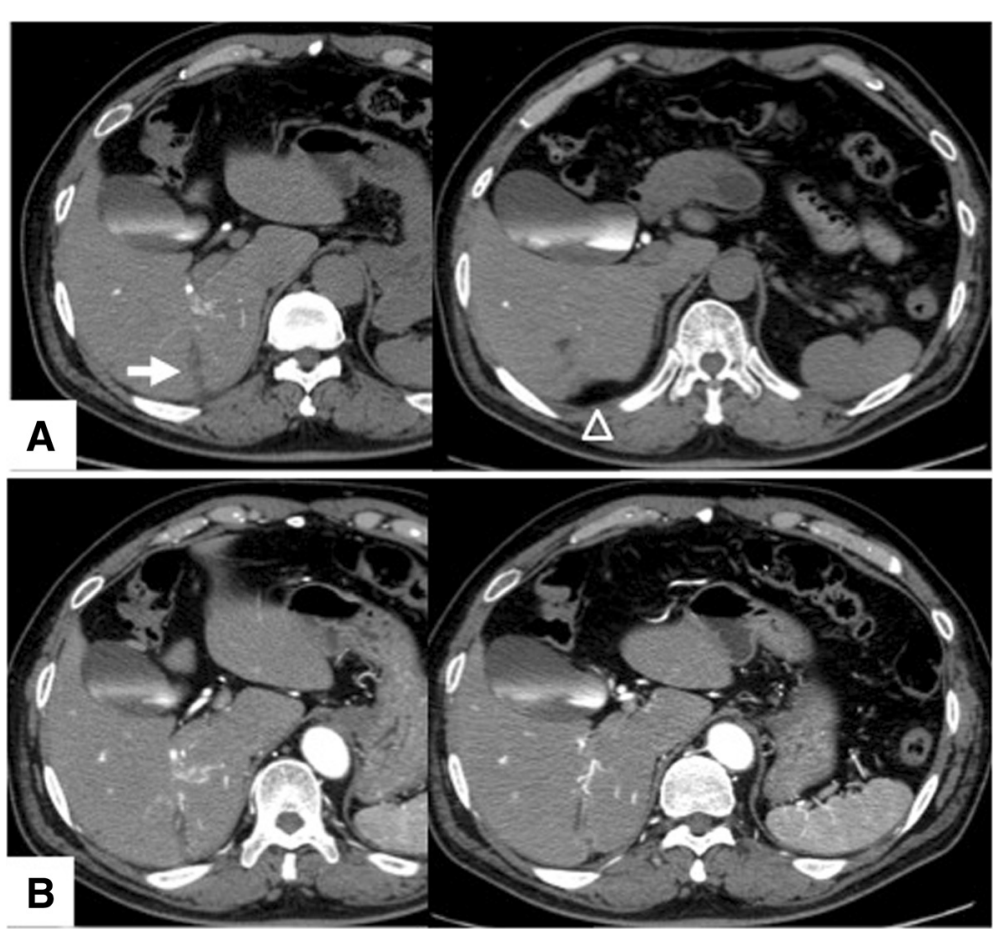

Fig. 1 Computed tomography findings. a Dynamic computed tomography with drip infusion cholangiography revealed focal dilatation of the biliary ducts (arrow) and atrophy (arrowheads) in the posterior segments of the liver. b No tumor was detected via enhanced computed tomography 


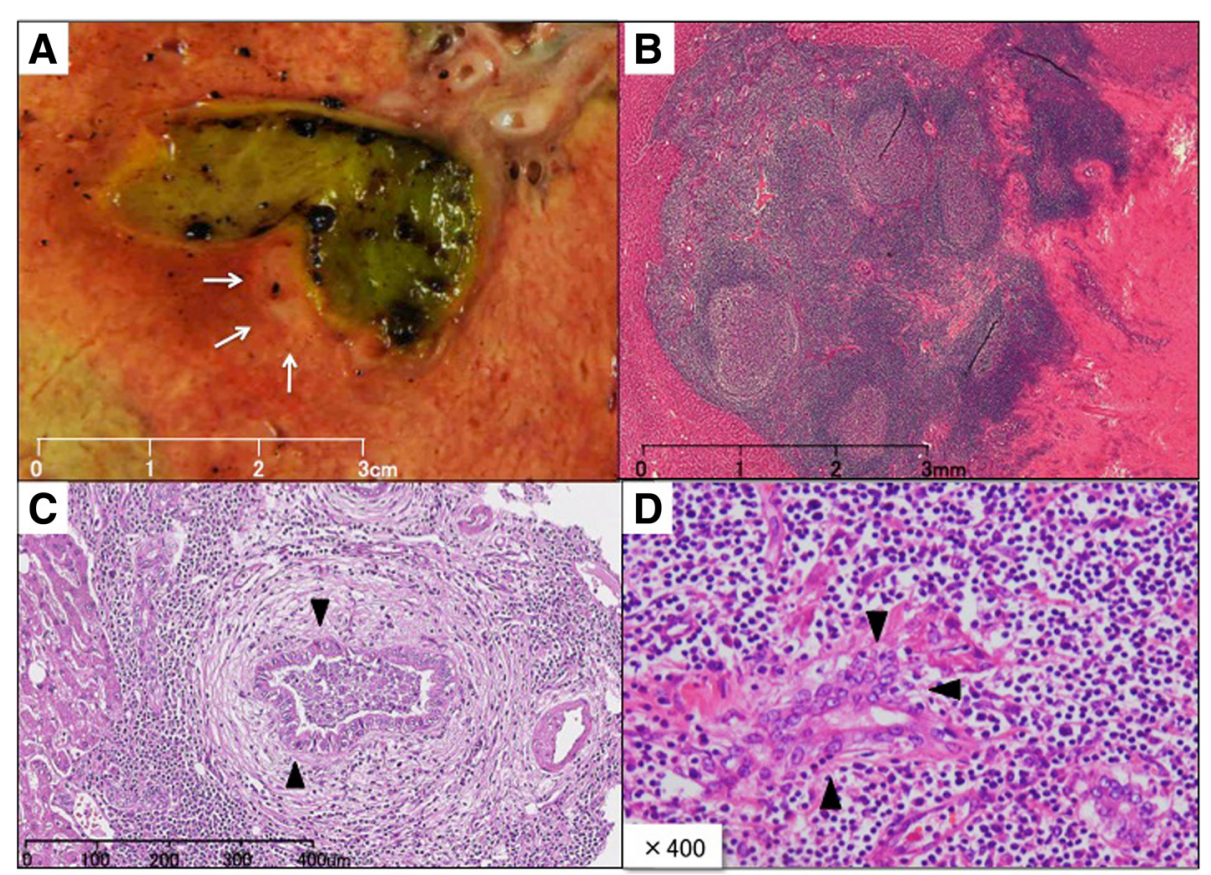

Fig. 3 Tumor characteristics. a Grossly, the 7-mm white mass along the posterior biliary duct was soft and non-encapsulated. b Histological findings on hematoxylin and eosin staining. The lesion consisted of dense lymphocyte infiltration with some lymph follicles. $\mathbf{c}$ and $\mathbf{d}$ Small to mid-sized lymphocytes formed lymphoepithelial lesions on some bile capillaries

treatment for pylorus eradication was provided. Biopsy of the bone marrow revealed a normoplastic marrow. Positron emission tomography demonstrated diffuse accumulation in both the thyroid glands, with a maximum standardized uptake value of 4.0. Biopsy of the thyroid glands showed chronic thyroiditis without malignancy, and the patient's thyroid function was within normal limits. The present case of MALT lymphoma was diagnosed a stage I tumor, according to the Ann Arbor classification, and careful follow-up without additional treatment was selected. At the time of this report, the patient remained alive and free of disease 2 years after surgery.

\section{Discussion}

MALT lymphoma often develops at several anatomic sites, including the gastrointestinal tract, lungs, head and neck, skin, thyroid glands, breasts, and liver. Gastric MALT lymphoma is thought to be triggered by chronic inflammation, which can occur in different diseases including chronic gastritis associated with HP infection, Sjogren syndrome, and Hashimoto thyroiditis [3]. The etiology of primary hepatic MALT lymphoma is unclear, but it has been reported that primary biliary cirrhosis [4-8], hepatitis $C$ viral infection [8-13], hepatitis B viral infection [14-16], ascariasis [17, 18], and HP infection [19] are possibly related with the pathogenesis of hepatic MALT lymphoma.

At presentation, our patient was not infected with hepatitis viruses, and his thyroid function and bone marrow were normal. He was also negative for anti-nuclear and anti-mitochondrial antibodies. However, his serum IgG and IgM levels were elevated, and he showed HP infection.

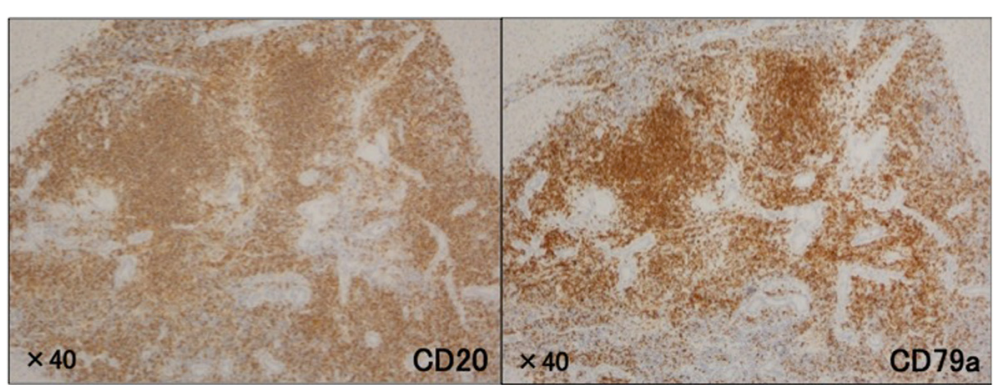

Fig. 4 Histological findings by immunohistochemical staining. Lymphocytes were diffusely positive for CD20 and CD79a antibodies 
Table 1 Reported cases of hepatic MALT lymphoma

\begin{tabular}{|c|c|c|c|c|c|c|c|}
\hline Case & Sex/age & HBV & $\mathrm{HCV}$ & Concomitant disease & Tumor no. & Treatment & Outcome \\
\hline 1 & $M / 66$ & ND & ND & Ureteral cancer & 1 & Resection & 12 M/alive \\
\hline 2 & $\mathrm{~F} / 73$ & ND & ND & $(-)$ & 1 & Resection & Lost to follow-up \\
\hline 3 & M/85 & ND & ND & Prostatic cancer & 2 & $(-)$ & Death after other surgery \\
\hline 4 & $\mathrm{~F} / 60$ & ND & ND & Liver cirrhosis & Multiple & Transplantation & $12 \mathrm{M} /$ dead \\
\hline 5 & $\mathrm{~F} / 57$ & $(-)$ & ND & Ascariasis & 1 & Resection & 55 M/alive \\
\hline 6 & $M / 48$ & $(+)$ & ND & Hepatitis & 1 & Resection + Chemotherapy & 38 M/alive \\
\hline 7 & $\mathrm{~F} / 47$ & $(-)$ & $(-)$ & Multiple biliary unilocular cysts & 1 & Resection + Radiation & 30 M/alive \\
\hline 8 & $M / 64$ & $(-)$ & $(-)$ & Colon cancer & 1 & Resection & Lost to follow-up \\
\hline 9 & $\mathrm{~F} / 62$ & $(-)$ & $(-)$ & Primary biliary cirrhosis & 1 & Resection & $6 \mathrm{M}$ /alive \\
\hline 10 & $F / 64$ & $(-)$ & $(+)$ & Liver cirrhosis & 1 & Chemotherapy & 24 M/alive \\
\hline 11 & $\mathrm{~F} / 65$ & $(-)$ & $(+)$ & Hepatitis & 1 & Chemotherapy & 48 M/alive \\
\hline 12 & $F / 69$ & $(-)$ & $(-)$ & $(-)$ & 1 & Resection & Short time/alive \\
\hline 13 & $F / 41$ & $(-)$ & $(-)$ & Primary biliary cirrhosis & 1 & $(-)$ & 12 M/alive \\
\hline 14 & $\mathrm{~F} / 64$ & $(-)$ & $(-)$ & $(-)$ & 1 & Resection & 72 M/alive \\
\hline 15 & $\mathrm{~F} / 57$ & $(-)$ & $(-)$ & Primary biliary cirrhosis & 1 & Transplantation & 9 M/alive \\
\hline 16 & $F / 64$ & $(-)$ & $(-)$ & Ascariasis & 1 & Resection & Pulmonary recurrence after $96 \mathrm{M}$ \\
\hline 17 & $F / 59$ & ND & ND & ND & Multiple & Resection + Chemotherapy & ND \\
\hline 18 & $M / 61$ & $(-)$ & $(-)$ & Gastric cancer & 1 & Resection & 18 M/alive \\
\hline 19 & $M / 73$ & $(-)$ & $(+)$ & Liver cirrhosis & 1 & Resection & 34 M/alive \\
\hline 20 & $M / 59$ & $(-)$ & $(+)$ & Hepatitis & 1 & Resection & 30 M/alive \\
\hline 21 & $\mathrm{~F} / 50$ & $(-)$ & $(-)$ & $(-)$ & 1 & Resection + Chemotherapy & 30 M/alive \\
\hline 22 & $F / 72$ & ND & ND & Colon cancer & 1 & $(-)$ & $1 \mathrm{M} /$ dead \\
\hline 23 & $\mathrm{~F} / 61$ & ND & ND & Rheumatoid arthritis & 1 & $(-)$ & Dead \\
\hline 24 & $F / 58$ & ND & ND & $(-)$ & Multiple & Resection + Chemotherapy & 37 M/alive \\
\hline 25 & $F / 62$ & ND & ND & Breast cancer & 1 & Resection & 9 M/alive \\
\hline 26 & $F / 65$ & $(+)$ & $(-)$ & Hepatocellular carcinoma & 1 & Resection & 10 M/alive \\
\hline 27 & $\mathrm{~F} / 60$ & $(-)$ & $(-)$ & Gastric MALT lymphoma & 1 & $(-)$ & 30 M/alive \\
\hline 28 & $M / 59$ & $(+)$ & $(-)$ & Liver cirrhosis & 2 & Transplantation & 6 M/Alive \\
\hline 29 & $M / 36$ & $(+)$ & $(-)$ & Hepatitis & 1 & Resection & Hepatic recurrence after $40 \mathrm{M}$ \\
\hline 30 & $M / 53$ & $(-)$ & $(+)$ & Liver cirrhosis & Multiple & Transplantation + Chemo & ND \\
\hline 31 & $M / 67$ & $(-)$ & $(-)$ & Hepatitis (drug) & 1 & Radiation & Pulmonary recurrence after $72 \mathrm{M}$ \\
\hline 32 & $M / 69$ & $(-)$ & $(-)$ & $(-)$ & 2 & RFA + Chemo & 24 M/alive \\
\hline 33 & $F / 74$ & $(-)$ & $(-)$ & $(-)$ & 1 & Resection + Chemotherapy & $6 \mathrm{M} /$ alive \\
\hline 34 & $F / 67$ & NA & NA & Gastric MALT lymphoma & Multiple & $(-)$ & $1 \mathrm{M} /$ dead \\
\hline 35 & $\mathrm{~F} / 72$ & $(-)$ & $(-)$ & Colon cancer & 1 & Resection & 24 M/alive \\
\hline 36 & $M / 64$ & $(-)$ & $(-)$ & Gastric cancer & Multiple & $(-)$ & 24 M/alive \\
\hline 37 & $\mathrm{M} / 71$ & $(-)$ & $(-)$ & $(-)$ & 1 & Resection & 15 M/alive \\
\hline 38 & $M / 71$ & $(-)$ & $(-)$ & $(-)$ & 1 & Resection + Chemotherapy & 45 M/alive \\
\hline 39 & $F / 56$ & $(-)$ & $(-)$ & $(-)$ & 1 & Resection & Pulmonary recurrence after $84 \mathrm{M}$ \\
\hline 40 & $M / 59$ & $(-)$ & $(-)$ & $(-)$ & 1 & Resection & 5 M/alive \\
\hline 41 & M/86 & $(+)$ & $(-)$ & Hepatitis & 1 & $(-)$ & 15 M/alive \\
\hline 42 & $M / 58$ & $(-)$ & $(+)$ & Hepatitis & 1 & Resection + Chemotherapy & 6 M/alive \\
\hline 43 & $F / 43$ & $(-)$ & $(-)$ & Gastric cancer & 1 & Resection & 24 M/alive \\
\hline 44 & $\mathrm{~F} / 80$ & $(-)$ & $(-)$ & Primary biliary cirrhosis & Multiple & Chemotherapy & ND \\
\hline
\end{tabular}


Table 1 Reported cases of hepatic MALT lymphoma (Continued)

\begin{tabular}{llllllll}
\hline 45 & M/76 & $(-)$ & $(+)$ & Hepatitis & 1 & Radiation & 60 M/alive \\
46 & F/74 & $(-)$ & $(-)$ & Colon cancer & 2 & Resection & 24 M/alive \\
47 & F/74 & $(-)$ & $(-)$ & Primary biliary cirrhosis & Multiple & Chemotherapy & 36 M/alive, no relapse \\
48 & M/73 & $(-)$ & $(+)$ & Hepatitis & Multiple & Chemotherapy & 24 M/alive, relapse \\
49 & F/56 & $(-)$ & $(-)$ & $(-)$ & 1 & Resection & 13 M/alive \\
50 & M/77 & $(-)$ & $(+)$ & Hepatitis & 1 & Resection & 8 M/alive \\
Our case & M/74 & $(-)$ & $(-)$ & $(-)$ & 1 & Resection & 30 M/alive \\
\hline
\end{tabular}

ND not detected

Such clinical findings suggested that the hepatic MALT lymphoma might be strongly associated with chronic inflammation caused by HP infection. Subsequent treatment for HP infection after surgery was successful.

For literature review, we searched PubMed and Ichushi Web by Japan Medical Abstracts Society independently. Key terms used included "MALT lymphoma," "liver," "hepatic MALT lymphoma," and "primary hepatic lymphoma. To our knowledge, there are 37 reports including 51 patients with primary hepatic MALT lymphoma [4-41] (Table 1). The mean age of these 22 men and 29 women was 64.0 years. In most cases, the hepatic tumors were incidentally detected during surgical resection or on follow-up imaging examination for liver diseases or other conditions. In 24 patients (47\%), liver diseases concomitantly existed (ascariasis, 2; primary biliary cirrhosis, 5; hepatitis B, 4; hepatitis C, 6; drug induced hepatitis, 1; cirrhosis without hepatitis viral infection, 5; and multiple biliary cysts, 1). Thus, hepatic MALT lymphoma development might be related to chronic liver inflammation, similar to gastric MALT lymphoma. Thirty-eight patients $(74 \%)$ had solitary mass, and the tumor size was $\leq 3 \mathrm{~cm}$ in 22 of the 41 reported cases (53\%). Regarding radiological characteristics, in 15 cases, the tumors were described as detectable hypo-echoic masses via abdominal US. In 21 cases, they were detected as low-density masses via $C T$, including 6 cases with enhancement and 9 without. In 16 cases with detailed MRI description, all tumors showed high density on T1-weighted images and low density on T2-weighted images. Two cases that described contrast-enhanced MRI showed sickly enhancement in the early phase. Both cases had solitary mass, and their tumor sizes were 3 and $6.5 \mathrm{~cm}$, respectively [27, 41]. Our case showed highly enhanced mass in the early phase, but not detected in abdominal US and CT. It is suggested that these findings would be specific to small hepatic MALT lymphoma. With regard to treatment, 31 patients (60.8 \%) underwent surgical resection with or without chemotherapy or radiation therapy. Of these, 28 patients had a single tumor, including 4 whose tumors were accidentally discovered in the isolated liver from transplantation patients. In addition, one patient underwent radiofrequency ablation, five received chemotherapy only, and two received radiation only. Eight patients did not receive any treatment, five of whom died during the follow-up period. Recurrence was reported in two patients.

According to the abovementioned case reports, primary hepatic MALT lymphoma tends to be solitary and small. Furthermore, it is often difficult to make a definite diagnosis of primary hepatic MALT lymphoma solely based on the imaging findings as the disease seem to exhibit variable imaging features. Therefore, it is necessary to accumulate more cases and establish a therapeutic strategy for primary hepatic MALT lymphoma.

\section{Conclusions}

In the present report, we described a case of primary hepatic MALT lymphoma. Our experience in this case and review of relevant literature indicated that preoperative diagnosis of hepatic MALT lymphoma might be challenging because of the disease's varying imaging features. Thus, further study of this extremely rare disease is necessary.

\section{Consent}

Written informed consent was obtained from the patient for publication of this case report and accompanying images.

\section{Abbreviations}

CT: computed tomography; HP: Helicobacter pylori; MALT: mucosa-associated lymphoid tissue; MRI: magnetic resonance imaging; PHL: primary hepatic lymphoma; US: ultrasonography.

\section{Competing interests}

The authors declare that they have no competing interests.

\section{Authors' contributions}

$\mathrm{SN}, \mathrm{NH}$, and KK drafted the manuscript. All authors read and approved the final manuscript.

\section{Acknowledgements}

We would like to thank Editage (www.editage.jp) for English language editing.

Received: 27 February 2015 Accepted: 17 September 2015 Published online: 24 September 2015

\section{References}

1. Isaacson P, Wright DH. Malignant lymphoma of mucosa-associated lymphoid tissue. Cancer. 1983;52:1410-6. 
2. Yang XW, Tan WF, Yu WL, Shi S, Wang Y, Zhang YL, et al. Diagnosis and surgical treatment of primary hepatic lymphomas. World J Gastroenterol. 2010;16:6016-9.

3. Thieblemont C, Bertoni F, Cople-Bergman C, Ferreri AJ, Ponzoni M. Chronic inflammation and extra-nodal marginal-zone lymphoma of MALT type. Semin Cancer Biol. 2014;24:33-42.

4. Prabhu RM, Medeiros LJ, Kumar D, Drachenberg Cl, Papadimitriou JC, Appleman HD, et al. Primary hepatic low grade B-cell lymphoma of mucosa-associated lymphoid tissue (MALT) associated with primary biliary cirrhosis. Mod Pathol. 1998;11:404-10.

5. Sato S, Masuda T, Oikawa H, Satoh T, Suzuki Y, Takikawa Y, et al. Primary hepatic lymphoma associated with primary biliary cirrhosis. Am J Gastroenterol. 1999;94:1669-73

6. Ye MQ, Suriawinata A, Black C, Min AD, Strauchen J, Thung SN. Primary hepatic marginal zone B-cell lymphoma of mucosa-associated lymphoid tissue type in a patient with primary biliary cirrhosis. Arch Pathol Lab Med. 2000;124:604-8.

7. Nakayama S, Yokote T, Kobayashi K, Hirata Y, Akioka T, Miyoshi T, et al. Primary hepatic MALT lymphoma associated with primary biliary cirrhosis. Leuk Res. 2010;34:e17-20.

8. Tanaka M, Fukushima N, Yamasaki F, Ohshima K. Primary hepatic extranodal marginal zone lymphoma of mucosa-associated lymphoid tissue type is associated with chronic inflammatory process. Open J Hematol. 2010. www.rossscience.org/ojhmt/articles/2075-907X-1-5.pdf. Accessed 14 Feb 2015.

9. Ascoli V, Lo Coco F, Artini M, Lerero M, Martelli M, Negro F. Extranodal lymphomas associated with hepatitis C virus infection. Am J Clin Pathol. 1998:109:600-9.

10. Yago K, Shimada H, Itoh M, Ooba N, Itoh K, Suzuki M, et al. Primary low-grade B-cell lymphoma of mucosa-associated lymphoid tissue (MALT)-type of the liver in a patient with hepatitis $C$ virus infection. Leuk Lymphoma. 2002;43:1497-500.

11. Mizuno S, Isaji S, Tabata M, Uemoto S, Imai H, Shiraki K. Hepatic mucosaassociated lymphoid tissue (MALT) lymphoma associated with hepatitis C. J Hepatol. 2002;37:872-3.

12. Orrego M, Guo L, Reeder C, De Petris G, Balan V, Douglas DD, et al. Hepatic B-cell non-hodgkin's lymphoma of MALT type in the liver explant of a patient with chronic hepatitis C infection. Liver Transpl. 2006;12:560-5.

13. Doi H, Horiike N, Hiraoka A, Koizumi Y, Yamamoto Y, Hasebe A, et al: Primary hepatic marginal zone B cell lymphoma of mucosa-associated lymphoid tissue type: case report and review of the literature. Int J Hematol. 2008;88:418-23.

14. Takeshima F, Kunisaki M, Aritomi T, Osabe M, Akama F, Nakasone T, et al. Hepatic mucosa-associated lymphoid tissue and hepatocellular carcinoma in a patient with hepatitis B virus infection. J Clin Gastroenterol. 2004;38:823-6.

15. Nart D, Ertan Y, Yilmaz F, Yüce G, Zeytunlu M, Kilic M. Primary hepatic marginal zone B-cell lymphoma of mucosa-associated lymphoid tissue type in a liver transplant patient with hepatitis B cirrhosis. Transplant Proc. 2005;37:4408-12.

16. Gockel HR, Heidemann J, Lugering A, Mesters RM, Parwaresch R, Domschke W, et al. Stable remission after administration of rituximab in a patient with primary hepatic marginal zone B-cell lymphoma. Eur J Haematol. 2005;74:445-7.

17. Yamabe H, Haga H, Kashu I, Watanabe C, Kobashi Y. Malignant lymphoma of mucosa-associated lymphoid tissue (MALT) type associated with ascariasis in the liver. Med Kagoshima Univ. 1995. http://ir.kagoshima-u.ac.jp/bitstream/ 10232/18332/1/AN00040104_v47s2_p137-139.pdf. Accessed 14 Feb 2015.

18. Chen F, Ike O, Wada H, Hitomi S. Pulmonary mucosa-associated lymphoid tissue lymphoma 8 years after resection of the same type of lymphoma of the liver. Jpn J Thorac Cardiovasc Surg. 2000;48:233-5.

19. Iida T, Iwahashi M, Nakamura M, Nakamori M, Yokoyama S, Tani M, et al. Primary hepatic low-grade B-cell lymphoma of MALT-type associated with helicobacter pylori infection. Hepatogastroenterology. 2007;54:1898-901.

20. Isaacson PG, Banks PM, Best PV, McLure SP, Muller-Hermelink HK, Wyatt II. Primary low-grade hepatic B-cell lymphoma of mucosa-associated lymphoid tissue(MALT)-type. Am J Surg Pathol. 1995;19:571-5.

21. Ueda G, Oka K, Matsumoto T, Yatabe Y, Yamanaka K, Suyama M, et al. Primary hepatic marginal zone B-cell lymphoma with mantle cell lymphoma phenotype. Virchows Arch. 1996:428:311-4.

22. Maes M, Depardieu C, Dargent JL, Hermans M, Verhaeghe JL, Delabie J, et al. Primary low-grade B-cell lymphoma of MALT-type occurring in the liver: a study of two cases. J Hepatol. 1997;27:922-7.

23. Kirk CM, Lewin D, Lazarchick J. Primary hepatic B-cell lymphoma of mucosa-associated lymphoid tissue. Arch Pathol Lab Med. 1999;123:716-9.
24. Bouron D, Léger-Ravet MB, Gaulard P, Franco D, Capron F. Unusual hepatic tumor. Ann Pathol. 1999;19:547-8.

25. Raderer M, Traub T, Formanek M, Virgolini I, Osterreicher C, Fiebiger W, et al. Somatostatin-receptor scintigraphy for staging and follow-up of patients with extraintestinal marginal zone B-cell lymphoma of the mucosa associated lymphoid tissue (MALT)-type. Br J Cancer. 2001;85:1462-6.

26. Murakami J, Fukushima N, Ueno H, Saito T, Watanabe T, Tanosaki R, et al. Primary hepatic low-grade B-cell lymphoma of the mucosa-associated lymphoid tissue type: a case report and review of the literature. Int J Hematol. 2002;75:85-90.

27. Arai O, Wani Y, Kaneyoshi T, Ikeda H, Kono Y, Tsukayama C. A case of primary hepatic low-grade B-cell lymphoma of mucosa-associated lymphoid tissue (MALT). Liver Cancer. 2003;9:144-9.

28. Streubel B, Lamprecht A, Dierlamm J, Cerroni L, Stolte M, Ott G, et al. $\mathrm{T}(14 ; 18)(\mathrm{q} 32 ; \mathrm{q} 21)$ involving IGH and MALT1 is a frequent chromosomal aberration in MALT Iymphoma. Blood. 2003;101:2335-9.

29. Shin SY, Kim JS, Lim JK, Hahn JS, Yang WI, Suh CO. Long-lasting remission of primary hepatic mucosa-associated lymphoid tissue (MALT) lymphoma achieved by radiotherapy alone. Korean J Intern Med. 2006;21:127-31.

30. Hamada M, Tanaka Y, Kobayashi Y, Takeshita E, Joko K. A case of MALT lymphoma of the liver treated by RFA and Rituximab. Nippon Shokakibyo Gakkai Zasshi. 2006;103:655-60.

31. Yasui T, Okino H, Onitsuka K, Shono M, Watanabe J, Takeda S. A case of primary hepatic lymphoma. Nippon Rinsho Geka Gakkai Zasshi. 2006. www.ci.nii.ac.jp/naid/130003605234. Accessed 14 Feb 2015

32. Chung YW, Sohn JH, Paik CH, Jeong JY, Han DS, Jeon YC, et al. High-grade hepatic mucosa-associated lymphoid tissue (MALT) lymphoma probably transformed from the low-grade gastric MALT Iymphoma. Korean J Intern Med. 2006;21:194-8.

33. Chatelain D, Maes C, Yzet T, Brevet M, Bounicaud D, Plachot JP, et al. Primary hepatic lymphoma of MALT-type: a tumor that can simulate a liver metastasis. Ann Chir. 2006;131:121-4.

34. Ito T, Hiramatsu K, Machiki Y, Akagawa T, Miyata T, Hirata A, Hara T, Yoshida K, Kato K. A case of resected mucosa-associated lymphoid tissue lymphoma of the liver. Jpn J Gastroenterol Surg. 2008. www.journal.jsgs.or.jp/pdf/ 041091686.pdf. Accessed 14 Feb 2015

35. Shito M, Kakefuda T, Omori T, Ishii S, Sugiura H. Primary non-Hodgkin's lymphoma of the main hepatic duct junction. J Hepatobiliary Pancreat Surg. 2008;15:440-3.

36. Koubaa Mahjoub W, Chaumette-Planckaert MT, Murga Penas EM, Dierlamm J, Leroy K, Delfau MH, et al. Primary hepatic lymphoma of mucosa-associated lymphoid tissue type: a case report with cytogenetic study. Int J Surg Pathol. 2008;16:301-7.

37. Murata T, Uetsuka H, Uda M, Kawamata O, Nakai H, Ohta T. A case of mucosa-associated lymphoid tissue lymphoma of the liver mimicking a metastatic liver tumor of gastric cancer. Nippon Rinsho Geka Gakkai Zasshi. 2009. https://www.jstage.jst.go.jp/article/jjsa/70/6/70_6_1799/_pdf. Accessed 14 Feb 2015.

38. Yoshida M, Sekikawa S, Takanashi S, Kashiyama M, Ishigooka M, Kawashima $\mathrm{H}$, et al. A resected primary hepatic mucosa-associated lymphoid tissue lymphoma with colon cancer. Nippon Rinsho Geka Gakkai Zasshi. 2010. www.ci.nii.ac.jp/naid/10026341055. Accessed 14 Feb 2015.

39. Hayashi M, Yonetani N, Hirokawa F, Asakuma M, Miyaji K, Takeshita A, et al. An operative case of hepatic pseudolymphoma difficult to differentiate from primary hepatic marginal zone B-cell lymphoma of mucosa-associated lymphoid tissue. World J Surg Oncol. 2011;9:3.

40. Miwa T, Yamamura Y, Fukuoka T, Mashita N, Inaoka K, Sawaki K, et al. A case of primary hepatic MALT Iymphoma, in which hepatocellular carcinoma was diagnosed in preoperative images. Kanzo. 2011. www.ci.nii.ac.jp/naid/ 10029526600. Accessed 14 Feb 2015.

41. Sakaguchi T, Kaibori M, Matsui K, Ishizaki M, Matsushima H, Kwon AH. A case of hepatic MALT lymphoma. Nippon Rinsho Geka Gakkai Zasshi. 2012. www.ci.nii.ac.jp/naid/130004518360. Accessed 14 Feb 2015. 